\title{
Single intrauterine demise in twin pregnancies: Analysis of 29 cases
}

\section{İkiz gebeliklerde tek intrauterin ölüm: Yirmi dokuz olgu analizi}

\author{
Senem Yaman Tunç1, Elif Ağaçayak1, Neval Yaman Görük², Mehmet Sait İçen1 ${ }^{1}$, Fatih Mehmet Fındık1, \\ Mehmet Sıddık Evsen1, Abdulkadir Turgut ${ }^{1}$, Serdar Başaranoğlu³, Ahmet Yıldızbakan1, Talip Gül1 \\ 1 Dicle University Faculty of Medicine, Department of Obstetrics and Gynecology, Diyarbakır, Turkey \\ ${ }^{2}$ Memorial Hospitals, Clinic of Obstetrics and Gynecology, Diyarbakır, Turkey \\ ${ }^{3}$ Fatih University Faculty of Medicine, Department of Obstetrics and Gynecology, İstanbul, Turkey
}

\begin{abstract}
Objective: To evaluate the maternal and fetal demographic features and clinical aspects of twin pregnancies with single intrauterine demise.

Materials and Methods: This retrospective study was conducted in Dicle University Faculty of Medicine, Department of Gynecology and Obstetrics between January 2008 and December 2013. There were a total of 594 twin deliveries in our hospital between the given dates. Twenty-nine of these cases were referred to our hospital by another health center because of a preliminary diagnosis of single intrauterine demise. Maternal age, parity, chorionicity, week of fetal death, gestational week at delivery, mode of delivery, birth weight, Activity, pulse, grimace, appearance, respiration scores, maternal fibrinogen levels at delivery and during pregnancy, stay in the neonatal intensive care unit, and obstetric complications were explored in these 29 cases of single intrauterine demise.

Results: The mean age of the 29 patients who were provided antenatal follow-up and delivery services in our hospital was $29.9 \pm 6.5$ years. Thirteen ( $44.8 \%$ ) of the patients were monochorionic, whereas $16(55.2 \%)$ were dichorionic. Intrauterine fetal death occurred in the first trimester in 6 pateints and in the second or third trimester in 23. In addition, 20 (69\%) patients underwent cesarean section, whereas 9 (31\%) had spontaneous vaginal delivery. Lastly, none of the patients had a maternal coagulation disorder.

Conclusion: Twin pregnancies with single intrauterine death can lead to various complications for both the surviving fetus and the mother. Close maternal
\end{abstract} and fetal monitoring, and proper care and management can minimize complications.

Keywords: Pregnancy, twin, single fetal death

$\ddot{O} z$

Amaç: İntrauterin tek fetal ölümlü ikiz gebeliklerin maternal ve fetal demografik özellikleri ve klinik açıdan değerlendirmektir.

Gereç ve Yöntem: Bu retrospektif çalışma Ocak 2008-Aralık 2013 tarihleri arasında Dicle Üniversitesi Tıp Fakültesi, Kadın Hastalıkları ve Doğum Anabilim Dalı'nda yapılmıştır. Bu tarihler arasında hastanemizde toplam 594 adet ikiz doğum olmuştur. Beş yüz doksan dört adet ikiz doğumun 29 'u ikiz eşinin intrauterin ölümü tanısı ile bize dış merkezlerden refere edilmiştir. İkiz eşinin intrauterin ölümü tanısı almış bu 29 olguda maternal yaş, parite, koryonisite, ikiz eşinin ölüm haftası, doğumdaki gebelik haftası, doğum şekli, doğum ağırlı̆̆ı, Etkinlik, nabız, yüz, görünüm, solunum skorları, gebelik sırasında ve doğumdaki maternal fibrinojen düzeyleri, yenidoğan yoğun bakım ünitesine yatış ve obstetrik komplikasyonlar değerlendirildi.

Bulgular: İkiz eşlerinden birinin intrauterin ölümü tanısı konan, antenatal takibi ve doğumu kliniğimizde gerçekleştirilen 29 olgunun ortalama yaşı

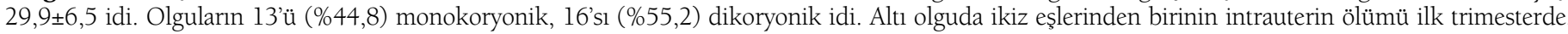
yirmi üç olguda ise ikinci trimester ve sonrasında gerçekleşmişti. Yirmi olgu (\%69) sezaryen ile, dokuz olgu (\%31) normal spontan vajinal yolla doğum yaptı. Maternal koagülasyon bozukluğuna hiçbir olguda rastlanmadı.

Sonuç: İkiz gebeliklerde tek fetusun intrauterin ölümü hem fetus hem de anne için çeşitli komplikasyonlara yol açabilir. Yakın maternal ve fetal izlem, uygun bakım ve yönetim komplikasyonları azaltabilir.

Anahtar Kelimeler: Gebelik, ikiz, tek fetal ölüm 
PRECIS: Twin pregnancies with single intrauterine death can lead to various complications for both the surviving fetus and the mother. Hence, these pregnancies should be followed up in a tertiary center. Close maternal- and fetal monitoring, and proper care and management can minimize complications.

\section{Introduction}

It has been reported that single intrauterine demise occurs in $5 \%$ of all twin pregnancies(1). The etiology is unknown in the majority of cases; however, twin-to-twin transfusion syndrome, Rh incompatibility, chromosomal and congenital abnormalities, preeclampsia, umbilical vein thrombosis, single umbilical artery, abnormalities arising from the location of placenta, and umbilical cord and uterine malformations are the main causes of fetal death in the rest of the cases(2-4). Single intrauterine demise may cause severe outcomes for the surviving fetus, especially in monochorionic twin pregnancies. Complications such as cerebral impairment, preterm labor and related sequelae, and subsequent death of the surviving fetus may occur in these cases(5).

Ideal management is uncertain in twin pregnancies complicated by single intrauterine demise. The best time for delivery, frequency of antenatal tests, and maternal effects are still under debate(6).

The purpose of this study was to explore the clinical features and fetal- and maternal outcomes of 29 twin pregnancies diagnosed as having single intrauterine demise.

\section{Materials and Methods}

This retrospective study was approved by Dicle University Faculty of Medicine, Board of Ethics (Ethics committee number: 356/10.06.2013). The study was conducted in Dicle University Faculty of Medicine, Department of Gynecology and Obstetrics between January 2008 and December 2013. Patients' data on age, parity, chorionicity, week of fetal death, gestational week at delivery, mode of delivery, birth weight, Activity, pulse, grimace, appearance, respiration (APGAR) scores, maternal fibrinogen levels at delivery, stay in the neonatal intensive care unit (NICU), and obstetric complications were evaluated.

Twenty-nine twin pregnancies complicated by single intrauterine demise were included in this study. The presence of twin pregnancy and type of chorionicity were explored in the previous ultrasonography report of the first trimester. The patients were divided into two groups according to chorionicity. Group 1 consisted of dichorionic patients and group 2 consisted of monochorionic patients.

To assess fetal development and well-being, ultrasonography, Doppler ultrasonography, and Non-stress test (NST) were used in the follow-up period after the diagnosis was established. Monthly follow-ups were scheduled for patients with normal results. All patients with pregnancies of gestational age less than 34 weeks were given steroids for fetal lung maturity. Maternal fibrinogen and thrombocyte levels were assessed every 2-3 weeks during pregnancy and at the time of delivery. Maternal fibrinogen levels were measured using a clotting system (Sysmex CA 7000 System with SIEMENS reagents).

The diagnosis of Twin-to-twin transfusion syndrome (TTTS) was based on the visualization of a separating membrane, polyhydramnios-oligohydramnios sequence in the absence of other causes of abnormal amniotic fluid volume, size discordance, abdominal circumference, or weight discrepancy greater than $20 \%$. Nonvisualization of donor's bladder, abnormal fetal Doppler studies, hydrops or evidence of congestive heart failure were other recognized findings of TTTS.

Statistical package for Social Sciences version 15.0 (SPSS Inc., Chicago, IL, USA) was used for statistical analysis of data. Kolmogorov-smirnov test was used for the determination of data distribution. Data that were normally distributed were expressed as mean \pm standard deviation, and non-normally distributed data were expressed as medians and ranges. The Mann-whitney U test and Chi-square test were used for comparisons between groups. A p value less than or equal 0.05 was considered statistically significant. Spearman's correlation analysis was used to determine correlation coefficients.

\section{Results}

There were 594 twin deliveries occurred in our clinic between January 2008 and December 2013. Among these, 33 patients were diagnosed as having single intrauterine demise. Four of the 33 patients were excluded from the study on the grounds of inaccessible data. The remaining 29 twin pregnancies complicated by single intrauterine demise were included in the study. The mean age of the patients was $29.9 \pm 6.5$ years. Ten (34.5\%) of the patients were primiparous, whereas 19 $(65.5 \%)$ were multiparous. Sixteen (55.2\%) patients were dichorionic (group 1) and 13 (44.8\%) were monochorionic (group 2).

Single intrauterine death occurred in the first trimester (before gestational week 14) in 6 patients and in the second or third trimester in 23 patients. Pregnancy was achieved spontaneously in $23(79.3 \%)$ patients, by in-vitro fertilization (IVF) in 3 (10.3\%), by intrauterine insemination (IUI) in one (3.4\%), and through ovulation induction in $2(6.9 \%)$ patients.

The mean gestational week at delivery was $33.7 \pm 3$. The mean interval between fetal death and delivery was $77 \pm 54$ days. The mean birth weight was $2116 \pm 719$ grams. The mean 1 -minute APGAR score was $5.8 \pm 1.5$ and the mean 5-minute APGAR score was $8 \pm 1$.2. The mean maternal fibrinogen level was $304.3 \pm 55.7$ $\mathrm{mg} / \mathrm{dL}$. The maternal and fetal features of groups 1 and 2 are shown in Table 1.

In group 1, 3 patients had preeclampsia, 2 had preterm labor, and 2 had early membrane rupture. In addition, one patient had a previous diagnosis of antenatal gastroschisis. The infants 
of 3 pateints were taken to the NICU following delivery. In group 1 , one newborn with gastroschisis was admitted to the intensive care unit. In addition, two newborns were admitted to the intensive care units because of prematurity. In group 2 , one patient had preeclampsia, one had early membrane rupture, one had intrauterine growth restriction (IUGR) and severe oligohydramnios, and 2 patients had TTTS. The infants of the patients with IUGR and TTTS were taken to the NICU following delivery because of prematurity and IUGR. None of the 29 patients had perinatal mortality. Furthermore, no patients had a maternal coagulation disorder. No statistically significant difference was found between the groups in terms of maternal fibrinogen levels at delivery $(\mathrm{p}>0.05)$.

The frequency of preterm delivery was $46 \%$ among monochorionic twin pregnancies (group 2) and $43 \%$ among dichorionic twin pregnancies (group 1). The difference between the groups was not statistically significant $(p>0.05)$.

There was a negative correlation between the mean gestational week of fetal death and the mean gestational week at delivery (Spearman's rho $=-0.380, \mathrm{p}=0.042$ ). Furthermore, no significant correlation was found between the mean gestational week of fetal death and mean fibrinogen levels $(\mathrm{r}=-0.317, \mathrm{p}=0.107)$.

\section{Discussion}

Single intrauterine demise in twin pregnancies is a serious complication that occurs in $2.6-5 \%$ of all cases $(1,7)$. In a study conducted in Turkey, the incidence of this complication was reported to be $3.3 \%(8)$. In the present study, the incidence was found to be $5.5 \%$, which was slightly higher than the rates reported in the literature. The higher incidence might have been caused by the fact that our hospital is a tertiary healthy center that provides services for the whole region.

It is known that the risk of preterm delivery is increased in twin pregnancies complicated by single intrauterine demise.

Table 1. Maternal and fetal features of the groups

\begin{tabular}{llll} 
& $\begin{array}{l}\text { Group 1 } \\
(\mathrm{n}=16) \\
\text { Mean } \pm \text { SD }\end{array}$ & $\begin{array}{c}\text { Group 2 }(\mathrm{n}=13) \\
\text { Mean } \pm \text { SD }\end{array}$ & p value \\
\hline Maternal age & $30.6 \pm 6.7$ & $28.9 \pm 6.3$ & 0.583 \\
\hline $\begin{array}{l}\text { Gestational week } \\
\text { at delivery }\end{array}$ & $33.3 \pm 3.4$ & $34.2 \pm 2.5$ & 0.551 \\
\hline $\begin{array}{l}\text { Birth weight } \\
\text { Maternal }\end{array}$ & $2059 \pm 831$ & $2186 \pm 577$ & 0.861 \\
fibrinogen level & $321.8 \pm 58.3$ & $285.5 \pm 47.8$ & 0.152 \\
\hline $\begin{array}{l}\text { 1-minute APGAR } \\
\text { score }\end{array}$ & $6.2 \pm 1.5$ & $5.3 \pm 1.4$ & 0.088 \\
\hline $\begin{array}{l}\text { 5-minute APGAR } \\
\text { score }\end{array}$ & $7.8 \pm 1.2$ & $8 \pm 1.1$ & 0.376 \\
\hline $\begin{array}{l}\text { Week of fetal death } \\
\text { SD: Standard deviation, APGAR: Activity, pulse, grimace, appearance, respiration }\end{array}$ & & & \\
\hline
\end{tabular}

Hilmann et al. (9) reported that the frequency of preterm delivery was $68 \%$ in monochorionic twin pregnancies and 54\% in dichorionic twin pregnancies. Similarly, Ong et al.(10) reported this frequency as $68 \%$ in monochorionic twin pregnancies and $57 \%$ in dichorionic twin pregnancies. The difference between the two groups was not found to be statistically significant. In agreement with the literature, in the present study the frequency of preterm delivery was $46 \%$ in monochorionic twin pregnancies and $43 \%$ in dichorionic twin pregnancies.

The mode of delivery should be selected according to the general obstetric condition of the mother in twin pregnancies complicated by single intrauterine demise. An early decision to perform a cesarean section owing to concerns of maternal coagulopathy should be avoided because it may cause prematurity-related problems for the fetus and increased morbidity for the mother ${ }^{(11)}$. In the present study, $69 \%(\mathrm{n}=20)$ of the cases underwent cesarean section, whereas 31\% ( $n=9)$ had spontaneous vaginal deliveries. Cesarean section was performed only in those patients with obstetric indications (10 patients with repeat cesarean sections, four patients with fetal distress, four patients with malpresentation, one patient with ablatio placenta, and one patient with fetal malformation).

Deveer et al.(6) reported that the mean gestational age at diagnosis of a single fetal death was negatively correlated with gestational age at delivery. In our study, there was a negative correlation between the mean gestational week of fetal death and the mean gestational week at delivery; our findings were consistent with their study.

There are few cases in the literature with maternal disseminated intravascular coagulopathy that occurred after the intrauterine death of one fetus in multiple pregnancies(12-14). Although some physicians administer short-term heparin to treat patients with hypofibronogenemia, it is known that it may resolve spontaneously without having to expose patients to treatment. In the present study, no patients had maternal coagulopathy. In addition, the difference between the two groups in fibrinogen levels at delivery and during pregnancy was not statistically significant.

Determination of chorionicity is important in twin pregnancies complicated by single intrauterine demise. Studies showed that prognosis was better in dichorionic twin pregnancies compared with monochorionic twin pregnancies(7). Hilmann et al.(9) reported that the frequency of mortality in the surviving fetus was 15\% in monochorionic twin pregnancies and 3\% in dichorionic twin pregnancies. Similarly, Ong et al.(10) reported this frequency as $12 \%$ in monochorionic twin pregnancies and $4 \%$ in dichorionic twin pregnancies. In the present study, no intrauterine mortality occurred in the surviving fetuses.

According to the literature, the perinatal mortality of monochorionic twin pregnancies is double that of dichorionic twin pregnancies(15). In our study, perinatal mortality was not observed in either group. This is likely to have been caused by the small number of patients in our study. 
The optimum management of twin pregnancies complicated by single intrauterine demise is still uncertain. Many studies present insufficient data as to the management strategy in such cases. There are limited data in the literature as to the frequency of urgent deliveries following single intrauterine demise(10). In our clinic, follow-up appointments take place every two weeks after gestational week 24 in twin pregnancies complicated by single intrauterine demise, and Doppler, non-stress test, and biophysical assessments are used to evaluate the current condition of the patient.

There are several limitations to our study. The relatively small number of patients and a lack of healthy twins as controls are ones to be noted. However, according to the literature, the loss of one twin in the first trimester does not appear to impair the development of the surviving twin(15). In our study, single intrauterine death in the first trimester (before gestational week 14) occurred in 6 patients. Another limitation of our study was the inclusion of these cases in the study.

In conclusion, twin pregnancies with single intrauterine death can lead to various complications for both the surviving fetus and the mother. Hence, these pregnancies should be followed up in a tertiary center. Close maternal- and fetal monitoring, and proper care and management can minimize complications. An early cesarean section should not be scheduled because of concerns of maternal coagulopathy, and prematurity should be avoided. Given the results of the present study, we recommend a conservative approach in twin pregnancies complicated by single intrauterine demise. However, larger studies are needed to determine the ideal management strategy in such patients.

\section{Authorship Contributions}

Ethics Committee Approval: The study were approved by the Dicle University of Local Ethics Committee, Informed Consent: Consent form was filled out by all participants, Concept: Senem Yaman Tunç, Mehmet Siddık Evsen, Talip Gül, Design: Senem Yaman Tunç, Elif Ağaçayak, Fatih Mehmet Findık, Data Collection or Processing: Senem Yaman Tunç, Ahmet Yildızbakan, Serdar Başaranoğlu, Analysis or Interpretation: Senem Yaman Tunç, Abdulkadir Turgut, Mehmet Sait İçen, Literature Search: Senem Yaman Tunç, Neval Yaman Görük, Writing: Senem Yaman Tunç, Peer-review: Externally peer-reviewed, Conflict of Interest: No conflict of interest was declared by the authors, Financial Disclosure: The authors declared that this study has received no financial support.

\section{References}

1. Kilby MD, Govind A, O'Brien PM. Outcome of twin pregnancies complicated by a single intrauterine death : a comparison with viable twin pregnancies. Obstet Gynecol 1994;84:107-9.

2. Peterson IR, Nyholm HCJ. Multiple pregnancies with single intrauterine demise: description of twenty-eight pregnancies. Acta Obstet Gynecol Scand 1999;78:202-6.

3. Baxi LV, Daftary A, Loucopoulos A. Single fetal demise in a twin gestation: Umbilical vein thrombosis. Gynecol Obstet Invest 1998;46:266-67.

4. Enbom JA. Twin pregnancy with intrauterine death of one twin. Am J Obstet Gynecol 1985;152:424-9.

5. Pharoah PO, Adi Y. Consequences of in-utero death in a twin pregnancy. Lancet 2000;355:1597-602.

6. Deveer R, Engin-Ustun Y, Mert I, Sarikaya E, Bozkurt S, Deveer M, et al. Twin pregnancies with single fetal death: Analysis of 38 cases. Fetal Pediatr Pathol 2013;31:71-5.

7. Carlson NI, Towers CV. Multiple gestation complicated by the death of one fetus. Obstet Gynecol 1989;73:685-9.

8. Aslan H, Gul A, Cebeci A, Polat I, Ceylan Y. The outcome of twin pregnancies complicated by single fetal death after 20 weeks of gestation. Twin Res 2004;7:1-4.

9. Hillman SC, Morris RK, Kilby MD. Co-twin prognosis after single fetal death: a systematic review and meta-analysis. Obstet Gynecol 2011;118:928-40.

10. Ong SCC, Zamora J, Khan KS, Kilby MD. Prognosis for the cotwin following single-twin death: a systematic review. BJOG 2006;113:992-8.

11. Cattanach SA, Wedel M, White S, Young M. Single intrauterine fetal death in a suspected monozygotic twin pregnancy. Aust N Z J Obstet Gynaecol 1990;30:137-40.

12. Mitra AG, Chescheir NC, Cefalo RC, Tatum BS. Spontaneous resolution of hypofibrinogenemia in a triplet gestation associated with second trimester in utero death of two fetuses. Am J Perinatol 1993;10:448-9.

13. Romero R, Duffy TP, Berkowitz RL, Chang E, Hobbins JC. Prolongation of a preterm pregnancy complicated by death of a single twin in utero and disseminated intravascular coagulation. Effects of treatment with heparin. New Eng J Med 1984;310:772-4.

14. Skelly H, Marivate M, Norman R, Kenoyer G, Martin R. Consumptive coagulopathy following fetal death in a triplet pregnancy. Am J Obstet Gynecol 1982;142:595-6.

15. Jain D, Purohit RC. Review of Twin Pregnancies with Single Fetal Death: Management, Maternal and Fetal Outcome. J Obstet Gynaecol India 2014;64:180-3. 